\title{
https://doi.org/10.46344/JBINO.2020.v09i04.15
}

\section{IS IT TIME TO REBOOT THE SYSTEM OF AYURVEDA IN INDIA?}

Dr Aakash Kembhavi, MD (Ayu - Shalya) \& Dr Anita Kadagad Kembhavi, MD (AYU - Kaya Chikitsa),

Director, Astanga Wellness Pvt Ltd, Hubli, Karnataka, India

(Received on Date: $4^{\text {th }}$ May 2020 Date of Acceptance: $22^{\text {nd }}$ May 2020 Date of Publish: 01 st July 2020)

Email id: drkembhavikpl@gmail.com

\begin{abstract}
The Covid 19 pandemic has thrown the entire world in a crisis of unfathomable proportions and the impact of this crisis can be felt for months on end. The global pandemic announced by the WHO was a golden opportunity especially for the Ayurveda system to have gotten its act together which unfortunately was wasted. The first request to set up an Ayurveda Task Force was sent by the authors of this article to the Prime Minister of India and the PMO through twitter on 24th March 2020. There have been a lot of representations from across India by like- minded Ayurveda people who were repeatedly requesting the authorities to involve Ayurveda in the fight against Covid 19. Co- incidentally, on the $2^{\text {nd }}$ of April, the ministry of Ayush set up a Task Force to address the issue, but as pointed out earlier we are yet to see any protocol recommended by the task force. The authors discuss about the infrastructure of Ayurveda in India and its inadequacies to address the issue. Certain solutions have been proposed and hopefully the powers that be take note of the situation and start taking reparative actions at the earliest as the question "Is it time to reboot the system of Ayurveda in India?" seems a pertinent one to ask.
\end{abstract}

Keywords: Covid 19, novel corona virus, Ayurveda, Ayush, Task Force, Reboot

\section{No: of References: 19}




\section{Introduction:}

The Covid 19 pandemic (1) has thrown the entire world in a crisis of unfathomable proportions and the impact of this crisis can be felt for months on end. Economic, social and health infrastructure are being tested like never before in the recent memory and every country in the world is doing its bit to tide over the crisis through collaborative efforts with each other.

The story of India though appears to be a bit better than others because of the proactive steps taken by the central as well as the state governments but we are yet to experience the full impact of the crisis as mass testing has just begun. The crisis is unfolding as this is being written and every section of the society is affected in one way or the other. The health ministry is working over- time to deal with the crisis. There is one ministry which was in deep slumber and slowly waking up to the reality: the ministry of Ayush.

\section{Setting the scene:}

The global pandemic announced by the WHO was a golden opportunity especially for the Ayurveda system to have gotten its act together which unfortunately was wasted. The reasons remain unknown.

The first Covid 19 positive case was identified in India on 30th January 2020 (2) and the first step to set up an Ayurveda task force to tackle this crisis was initiated on the $2^{\text {nd }}$ of April 2020 (3) which even after a week of its constitution has not come out with any recommendations yet. Again, the reasons for this delay remain unknown. When the entire medical system is working in an emergency mode to find a cure it remains a mystery as to why Aurveda as a system is not responding actively. Probably, it is living up to its image that
"Ayurveda is slow to act". Kerala (4) and Goa governments (5) have given the go ahead to start using Ayurveda medicines in the treatment of Covid 19 cases. The Sri Lankan government (6) too has called upon its Ayurveda doctors to find a cure for this pandemic.

The first request to set up an Ayurveda Task Force was sent by the authors of this article to the Prime Minister of India and the PMO through twitter on $24^{\text {th }}$ March 2020 (7). This tweet was then sent to Dr Harshavardhan, the CM of the state of Karnataka, the Health Minister of the state of Karnataka and Dr Shashi Tharoor and media outlets like NDTV, NewsX, India Today, PTI etc (8). The request to the PM was sent again on $25^{\text {th }}$ March 2020 (9). A request was sent through twitter to Sri Arvind Kejriwal and Sri Manish Sisodia as well on the $2^{\text {nd }}$ of April 2020. On 2nd April 2020 (10). A proposal to constitute an Ayurveda Task Force was submitted to the PM and the PMO (11). The authors have not received any response whatsoever from anyone till date. There have been a lot of representations from across India by like- minded Ayurveda people who were repeatedly requesting the authorities to involve Ayurveda in the fight against Covid 19. Co- incidentally, on the $2^{\text {nd }}$ of April, the ministry of Ayush set up a Task Force (12) to address the issue, but as pointed out earlier we are yet to see any protocol recommended by the task force.

So far, there has been no national policy or guidelines issued by the Ministry of Ayush with regards to the protocol for management of Covid 19 cases. In such a scenario, it seems wishful thinking that we will receive any guidelines on how our clinical practice should be post relaxation of the Covid 19 lockdown directives. 
During the course of the crisis from Jan 30th, 2020 onwards till date there are no guidelines with regards to how an Ayurveda practitioner should continue with clinical practice.

It was a very simple thing that could have been done:

\section{The Ayurveda infrastructure in India (13):}

There are nearly 339 Ayurveda Colleges with an intake capacity of 21,387 seats at the undergraduate level and 4122 seats at the post- graduate level.Each college has a hospital which is adequately equipped with wards and semi-private and private beds. There are nearly 10 lakh registered Ayurveda practitioners across India and about 8000 registered Ayurveda medicine manufacturing companies. With such a huge work force and infrastructure, it is indeed sad that we as a system are not doing anything to help in this crisis when the modern medical system "corona warriors" are sacrificing their time and lives to tackle the crisis. It is indeed shameful. A sense of betrayal, hopelessness and depression is being felt across the length and breadth of India amongst Ayurveda physicians who sincerely believe that Ayurveda can help. WhatsApp groups are filled with such discussions and everyone is sharing their ideas and experiences. The one question that everyone is trying to find an answer is - How and Why did we reach this stage?

\section{What is wrong with the system?}

The main worry is that Ayurveda as a science has been neglected for decades and stop gap arrangements and policies were formulated to run the system with meagre funding compared to the modern medical science. The curriculum of both the undergraduate and the post graduate levels are framed more on the lines of modern medical curriculum and it is a concern that a vast majority of practitioners of Ayurveda across India are demanding that they be allowed to use allopathic medicines. This shows the system has not been able to stem the rot and Ayurveda as a science of well- being is neglected. Every healthcare approach has its own limitations and certainly Ayurveda too has its own and the science needs to grow within these limitations and collaborate with other healthcare systems to provide an integrated approach to health and wellbeing.

Academic and clinical skills development need a complete overhaul. The quality of teaching is below par in a vast majority of institutions as there is no system to train and develop quality teachers. Merit does not play a role in the education system and there are no compulsions on performance oriented academic indicators as advised by the UGC. It is followed in only a handful of government run institutions. CMEs to gather credits is non- existent in the system. There is no recognition of additional qualifications which a teacher acquires either in terms of appreciation or monetary gains. A standard minimum pay structure is not existent and there are huge discrepancies in salaries across the country.

Though there are regulatory bodies who have drafted guidelines known as minimum standards requirements (MSR) (14) to regulate Ayurveda colleges and hospitals, it is an going to be an uphill battle to cleanse the system of its corrupt past through the newly passed NCISM bill (15). The Central Council of Indian Medicine (CCIM), which was the recommending body until now will be dissolved. The future seems uncertain with 
a lot of stakeholders waiting to capitalise. The ministry of Ayush has released a note saying that advertising related to benefits of Ayurveda medicines should be avoided (16) and has released immunity boosting measures according to Ayurveda till now (17).

The MSR is unscientific in many aspects and needs a complete revision. To highlight an example: A certain minimum number of teachers have been recommended to be appointed for colleges opting for 60 or 100 student intakes at the undergraduate level. Cadre- wise division is recommended as well, but a casual glance at the number of teachers available in the country will tell that there is an acute paucity of teachers. To complicate matters, new colleges are permitted to start which strains the already stretched academic challenges. How can one expect that quality teachers and teaching will exist in such a scenario? To further add salt to injury, there is no transparent policy on requirement of post graduate teaching faculties. All colleges are working within this system and each has developed their own mechanism of surviving the unscientific yearly inspections conducted by the apex bodies. Teachers are unnecessarily targeted with compulsions of submitting affidavits and legal action. The system just does not want to understand that visiting and honorary teachers can solve the problems. A vast pool of experienced clinicians who can share their experiences with students are not part of the teaching system at all. How can one expect that well trained and skilled practitioners pass out each year and is it not a great disservice that we are doing to the population who expect that their doctors are professionally trained and qualified?
There are many such unscientific minimum standard recommendations.

Then there are the yearly inspections carried out by the apex body through a team of inspectors appointed by it. There are no criteria to be appointed as an inspector except that one must be a professor in a government run Ayurveda college. During the process of inspection, there is a physical verification of the length and breadth of the college and the hospital and the teaching faculties are treated as though they are second class citizens. It has been the experience of the authors in the 25 odd years of attending these inspections that not even one of them were conducted with the intention of knowing the outcome of the college in terms of their graduates or post graduates being of service to the society or to understand the quality of teaching. The students are never ever questioned and even if they are it is just a mere formality. To top the show that goes on, every inspection is video- recorded and photos are clicked. The hospital verification is a huge circus that goes on. The beds are decked up and patients are created. All this because there is a minimum requirement of a certain number of patients that must be recorded every day. When the entire medical fraternity is for early discharge of patients our system mandates that we admit patients for as long as possible even in the ophthalmic unit. Such unscientific regulations have created a niche area for corrupt practices which are now being outsourced to people who manage the show professionally and all this just to get permission for the next academic year. Why does it have to be such a farce? Are the authorities unaware of the ground reality? Surely a better system of affiliation can be implemented. Unfortunately, inspections 
have become a fault- finding endeavour rather than a fact- finding exercise.

There is an urgent need to edit, revise and reprint the basic texts of Ayurveda called as Samhitas and there is a very disturbing trend of writing textbooks which are more of a compilation work rather than books which inspire and motivate the students. The examination system too is highly unscientific where the questions framed are based on rote learning methods rather than critical analysis which is generally expected of a physician. There is no provision for revaluation and counter questioning the evaluators which defeats the very purpose of education. There is an environment of fear amongst the students and the teachers exercise this weapon with superlative skills to control the students.

The post graduate scenario is more pathetic than the under-graduate. At the post graduate level, one expects a research oriented critical analytical approach which is sorely missing. A cursory glance at the research topics selected for the dissertations highlights a disconnect with the current emerging trends in the health care sector. A vast majority of the teaching faculties are blissfully unaware of the research methods and bio- statistics principles which are the very basis of a post graduate learning. Institutions are poorly equipped to teach at this level. Postdoctoral degrees are awarded for very simple studies which do not have any scientific significance at all. There are no guidelines whatsoever from either the ministry of Ayush, CCIM or the state- run health universities for conducting research. What is more worrying is that even a template to submit synopses based on different research designs is non- existent. Is it not basic logic that because we have nearly 16 branches of post graduate disciplines, each branch should have its own research synopsis template? Why can't the authorities not understand such simple aspects?

Another major drawback is that there is no connect between the students once they pass out of the institutes. There is no support system to help and guide them. It is a bitter truth that a vast majority of students who pass out practice allopathy because of the lack of clinical and disease management skills according to Ayurveda. There is no other option for the students as they have family and financial obligations to fulfil. There are extremely limited prospects for growth in the clinical field and everyone develops his or her own strategy to survive. Why should the students be blamed for the short- sighted policies of the system?

Unethical clinical practices rule the day as commission-based practices are rampant. Ayurveda practitioners feed patients to allopathic hospitals and it is here that everything starts getting hazy. There are no guidelines. The concept of CMEs and credits for professional development is non- existent. Latest guidelines of Ayurveda clinical management are not published at all. In such a scenario how can one expect that Ayurveda practitioners give their best to the society?

Coming to the pharma sector, there are nearly 8000 registered pharmacies and the regulatory body is inefficient and there is a disconnect between the pharma and the academic and clinical research and development activities. Major pharma companies conduct their independent in-house research and development without association with institutions and centres. This does not 
augur well for the holistic development of Ayurveda. There must be a mechanism where research and development is a co-ordinated and collaborative activity.

Coming to the latest development in the past few years, many foreign Ayurveda centres have opened up and are offering courses of all hues and colours in everything under the umbrella of Ayurveda. There is no regulation of these, and neither is it mandatory to be affiliated or at least be permitted by the ministry. Is it not logical that a science which has its roots in India should have regulatory body in India? Why can't the authorities set minimum standards for these mushrooming centres across the world? We can certainly collaborate with governments across the world now that Ayurveda is accepted all over.

The tragedy with Ayurveda as a system is that whenever a new medical issue surfaces the standard response is - Oh, but it's already described in Ayurveda! To cite an example, The Nobel Prize in Physiology or Medicine 2017 was awarded jointly to Jeffrey C. Hall, Michael Rosbash and Michael W. Young "for their discoveries of molecular mechanisms controlling the circadian rhythm." Instead of appreciating the tremendous scientific work put in by the two winners, a vast majority of Ayurveda faculty and practitioners ended up with statements like - "these concepts have been described in Ayurveda thousands of years ago". Yes, nobody denies the fact, but the question is - why did we not do something about it? The system is still stuck in the past glory of Ayurveda and there is an urgent need to recognize that if we want the world to understand Ayurveda and its usefulness as a health and well-being science, we have to come out of our cocoon and provide evidence and create awareness of what traditional and authentic Ayurveda really is.

These are just a few things which are discussed above. Any robust system must have checks and balances which does not exist in Ayurveda. These are what the authors feel that are not existing in the system which is why it functions the way it does presently.

\section{The following do not exist in the system of Ayurveda:}

1. A transparent system of regulation and inspection

2. National association of students (both UG and PG)

3. National association of teachers

4. National association of practitioners

5. A National Research and development wing with zonal branches

6. A National and / or Zonal Grievance or Redressal cell

7. Consultation process to implement ideas and suggestions

8. Feedback system

9. Regulatory body to regulate clinics, hospitals, resorts and spas etc that are exploiting Ayurveda

10.Zonal representations in the ministry

11. Focussed curriculum development to meet the challenges of the everchanging health issues

12. Clinical and Research Skill enhancement of the students and teachers

13. A robust pharmacovigilance body and pharma regulating body

14. Industry collaboration

15. Merit based promotions in academic institutions

16. A strategic response clinical apex body to address health challenges of the country 
17. Advisory body to co- ordinate with the WHO and other countries to implement Ayurveda principles in health care

Patriarchal mindset, patronising attitudes, corruption and inflated egos have destroyed the very core of the system of Ayurveda. Ayurveda as a science is not developed at all. Only a handful few influential people steal the limelight. There are far more brilliant minds in Ayurveda who do not have an avenue to share their ideas and suggestions and thus the science suffers in silence, which brings us to the important question: IS IT TIME TO REBOOT THE SYSTEM OF AYURVEDA?

The present crisis could have been used as golden opportunity to showcase to the entire world that Ayurveda can help in tackling the medical crisis of Covid 19. If the authorities in our system had taken a pro-active role much before the crisis hit India and prepared a protocol to address the issue, probably our Prime Minister would have believed in us and would have given the green signal. It would have been a great opportunity to tell the world that India believes in its traditional health care system to augment and support the modern medical system in its fight against the deadly virus and it would have been a protocol which other nations could have tried.

\section{Proposed Solutions:}

The present pandemic has exposed the short comings in the system of Ayurveda, and it should be considered as a wakeup call to reboot it to make it a more robust, responsible and a responsive healthcare system. The reboot should hopefully lead to the quarantining and deletion of the virus of corruption and inaction that is plaguing Ayurveda. The big question is who should press the RESET button to reboot Ayurveda? The authors have published a paper in The Journal of Natural and Ayurvedic Medicine titled "Reforms in Ayurveda Education : Challenges and Roadblocks" where they have discussed about the educational reforms necessary in Ayurveda Education (18).

Based on decades of academic and clinical experience and having closely associated with many teaching institutions and having understood the functioning of Ayurveda as a system, the authors hereby propose that the following can be done to reboot Ayurveda:

1. A more robust, transparent system of inspection where merit decides the eligibility to be an inspector

2. The ministry of Ayush should set up an independent National Ayurveda Task Force consisting of representatives from five zonal task forces from all parts of India, who should report directly to the minister. The details of setting up this can be worked out, but the criteria of selection should be based on merit. This should be independent of any bureaucratic red tapism. Separate funds should be allocated.

3. Set up a National Association of Teachers of Ayurveda

4. Set up a National Association of UG and PG students of Ayurveda

5. An apex regulatory body of Ayurveda to regulate the practice of Ayurveda and to prevent its exploitation

6. Text- books regulatory authority

7. A National Continued Professional Development Cell with zonal branches should be set up 
8. An apex Research and Development wing should be set up

9. An Apex Ayurveda Pharma Regulatory body with zonal representative bodies

10. A National Level Ayurveda Diet and Nutrition centre should be set up

11. A grievance and redressal body should be set up like the comptroller and auditor general for Ayurveda

12. A National Level Ayurveda Clinical Skills development body should be set up

13. Curriculum designing and development wing should be separately set up

14. A state-of-the-art National Level Ayurveda Research Laboratory with an independent body should be set up

15. An Ayurveda Clinic and Hospital management software should be developed and implemented across the country as a standard template for data collection

16. Collaborative initiatives with Pharma industry, IT, engineering and other allied sciences as well as use of $\mathrm{Al}$ to provide employment opportunities and to develop Ayurveda as a global health care system

17. A National Level Ayurveda Strategic Response Team should be constituted with the best of the academicians, clinicians and research scientists in Ayurveda to collaborate with the modern medical system to include Ayurveda as a treatment strategy in national health care initiatives

18. Extensive Insurance coverage to people who want to seek
Ayurveda consultation and treatments

19. Professional indemnity insurance for all Ayurveda doctors should be made compulsory

20. An Ayurvedic Comptroller and Auditor general should be appointed

21. A Global Ayurveda Network should be initiated

Merit should be the sole criteria to set up these recommendations and there should be a transparent system to get these done otherwise it will defeat the very purpose of rebooting the system. Autonomous status should be given to the above-mentioned task forces and bodies suggested.

These are just a few initial steps that should be taken immediately to address the tardiness of the system of Ayurveda. Ayurveda as a system must be woken up from its deep slumber and the REBOOT has to begin now to restore the glory of Ayurveda as a science of health and well- being which has global reach and appeal.

It is time to prove that Ayurveda has the potential to be a contender in tackling the health challenges of the present and the future because it seems that we are going to learn to live with such new diseases for a very long time.

The views expressed here are of the authors and it is an eternal hope that Ayurveda as a science can regain its lost glory.

\section{Source of Funding: None}

Conflict of Intetest: None 


\section{References}

2. https://www.who.int/dg/speeches/ detail/who-director-general-sopening-remarks-at-the-mediabriefing-on-covid-19---11-march2020

3. https://www.google.com/urlesa=t\& source=web\&rct=j\&url=https://ww w.indiatoday.in/amp/india/story/c oronavirus-in-india-trackingcountry-s-first-50-covid-19-caseswhat-numbers-tell-1654468-2020-03$12 \&$ ved=2ahUKEwi8uofJ5_ToAhUSU 30KHes8DrUQFjAZegQIBRAB\&usg $=A$ OvVaw3rLfebpVejeHAXUSa5bS5f\& ampcf $=1$

4. https://www.google.com/url? sa=t\& source=web\&rct=j\&url=https://india nexpress.com/article/coronavirus/a yush-task-force-on-covid-19-looksat-promising-ayurvedic-medicinesfor-clinical-drug-trials-

6362755/lite / \&ved=2ahUKEwiEts735f ToAhUGeysKHVOFDcoQFjAGegQIA hAB\&usg=AOVVaw16VxOW12dgCJb77tGV08U\&ampcf $=1$

5. https://www.google.com/amp/s/m edicaldialogues.in/amp/statenews/kerala/kerala-plans-on-usingayurveda-to-mitigate-covid-19spread-64755

6. https://www.google.com/amp/s/w ww.deccanherald.com/amp/natio nal/west/goa-to-use-ayurveda-toboost-immunity-of-patients-ofcoronavirus-823368.html

7. https://www.google.com/amp/s/w ww.thestatesman.com/world/srilankan-govt-requests-ayurvedicmedical-practitioners-cure-covid19-1502875487.html/amp
8. https://twitter.com/drkembhavi/sta tus/1242387776810684417?s=19

9. https://twitter.com/drkembhavi/sta $\underline{\text { tus/ } 1242508712868302852 \text { ? } \mathrm{s}=19}$

10. https://twitter.com/drkembhavi/sta tus/1242515621301997568?s=19

11. https://twitter.com/drkembhavi/sta tus/1243431169649250304?s=19

12. https://twitter.com/drkembhavi/sta tus/1245727645800828933?s=19 hu

13. https://www.nutraingredientsasia.com/Article/2020/04/15/COVI D-19-in-India-AYUSH-Ministry-seeksscientific-validation-of-traditionalmedicines-after-initial-backlash

14.http://main.ayush.gov.in/

15. https://ccimindia.org/rul-reg-msr2016-9-7

16. https://www.prsindia.org/billtrack/n ational-commission-indian-system$\underline{\text { medicine-bill-2019 }}$

17.https://www.ayush.gov.in/docs/121 .pdf

18. https://www.ayush.gov.in/docs/123 .pdf

19.Kembhavi A, Kembhavi AK. Reforms in Ayurveda Education: Challenges and Roadblocks. Journal of Natural and Ayurvedic Medicine 2020; 4(1) 